プによつている。

保安については, 話し合いによる保安教育を強化し, 保安懇談会, 300 事故報告カードの推進によつて, 保安 意識の昂揚につとめている。

\section{5. 問題点と将来の計画}

電気探鉱, 試錐探鉱, 坑道探鉱の徹底的強化により, 獲得鉱量の増加を図り，安定操業への基礎づくりに邁進 しなければならない。

\section{6. 過去10年間の年間出鉱量, 平均品位およ び能率（坑内, 全山）の推移}

（第 4 図，第 6 表参照）

\begin{tabular}{|c|c|c|c|c|c|c|c|c|c|c|c|}
\hline \multirow[b]{2}{*}{ - } & \multirow{2}{*}{$\begin{array}{c}\text { 年間出錇量 } \\
(\mathrm{t})\end{array}$} & \multicolumn{2}{|c|}{ 平均品位 $(\%)$} & \multicolumn{2}{|c|}{1 人 1 力月当り出鉱量 } & & \multirow{2}{*}{$\begin{array}{c}\text { 年間出鉱量 } \\
(\mathrm{t})\end{array}$} & \multicolumn{2}{|c|}{ 平均品位 $(\%)$} & \multicolumn{2}{|c|}{ 1人1力月当り出鉱量 } \\
\hline & & $\mathrm{Cu}$ & $\mathrm{S}$ & 坑内 $(t)$ & 全山( $\mathrm{t}$ ) & & & $\mathrm{Cu}$ & $\mathrm{S}$ & 坑内 $(t)$ & 全山( $t$ ) \\
\hline 32年 & $167 ; 792$ & 1.44 & & 45 & 26 & 39 & 48,015 & 1.43 & & 51 & 25 \\
\hline 33 & 131,040 & 1.45 & & 36 & 22 & 40 & $\begin{array}{r}* 21,210 \\
42,611\end{array}$ & 1.15 & $* 18.59$ & 44 & 34 \\
\hline 34 & 154,992 & 1.38 & & 43 & 26 & & $\begin{array}{r}42,611 \\
* 21,391\end{array}$ & 13 & $* 19.45$ & & \\
\hline $\begin{array}{l}35 \\
36\end{array}$ & $\begin{array}{r}168,621 \\
* 7,803\end{array}$ & 1.39 & $* 20.92$ & 49 & 31 & 41 & $\begin{array}{r}51,739 \\
* 50,431\end{array}$ & & $* 19.65$ & & 40 \\
\hline $\begin{array}{l}36 \\
37\end{array}$ & $\begin{array}{l}172,128 \\
104,217\end{array}$ & $\begin{array}{l}1.27 \\
1.37\end{array}$ & & $\begin{array}{l}54 \\
50\end{array}$ & $\begin{array}{l}37 \\
35\end{array}$ & 計 & $1,080,285$ & 1.36 & & $47 \bar{\jmath}$ & 299 \\
\hline 38 & 45,130 & 1.54 & & 46 & $\begin{array}{l}35 \\
23\end{array}$ & 平 均 & $\begin{array}{r}* 5,043 \\
108,029\end{array}$ & 1.36 & $* 19.65$ & 48 & 30 \\
\hline
\end{tabular}

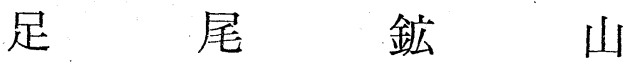

\title{
Ashio Mine
}

\section{1. 緒言}

位置; 当所は日光市の西南 $30 \mathrm{~km}$, 桐生市の北方 $42 \mathrm{~km}$ の渡良瀬川源流に位置し，交通，資材の搬入などには主 として国鉄足尾線を使用し，粗銅は日足道路を経て日光 精銅所へトラックで運ばれる。

沿革；1610年発見以来徳川幕府の直轄銅山となり，以 後幾多の変遷を経て, 明治10年古河の経営するところと なつた。明治17年本口坑において，大富鉱脈，横間歩銿 が発見され足尾繁栄の基礎が作られた。

明治中期以降, 本山, 小滝, 通洞の三坑より多数の鉱 脈之河鹿鉱床が開発され，大正から昭和の初期にかけて は, 年産粗銅 $16,000 \mathrm{t}$ に達した。

しかし, 終戦直後には第二次大戦中の乱掘のため, 年 産粗銅 $1,200 \mathrm{t}$ にまで落ちたが, その後の探鉱と合理化 により，現在は年産粗銅 6,000 t にまで回復した。

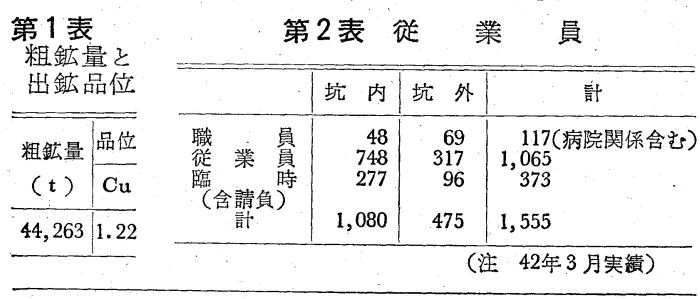

* 古河釷業株式会社足尾鉱業所

$$
\begin{gathered}
\text { 正会員高 松 剛 毅* } \\
\text { Gōki TAKAMATSU }
\end{gathered}
$$

古河の経営に移つて以来今日まで66万 $\mathrm{t}$ 余の銅を産出 し, 現在は小滰坑を廃して本山, 通洞の両坑住, 通洞 レベルより上に20坑道,下に14坑道の閒を稼行している。 現状;（第 1,2 表参照）

\section{2. 地質, 鉱床の概況}

足尾鉱山の鉱床は, 秩父古生層中と足尾流紋岩中とに 賦存して抒り, 秩父古生層は主として砂岩, 粘板岩, 于 ヤートより成り，全般的に北東の一般走向を有するが， 有越, 連慶洔付近では反転して褶曲地帯を構成してい る。全体として陥没による盈状地形を呈し，鈗床の基盤 岩となつている。

足尾流紋岩はこの盈状地形の下部より第三紀中新世に 噴出したものと推定され，これを埋めて漏斗状の形態を 示しており，地表でほ長径 $4.4 \mathrm{~km}$, 短径 $3.3 \mathrm{~km}$ の棈円 状に発達する。上半分は主として熔結流紋岩質凝灰岩よ りなり，その間に凝灰角磁岩を挾在する。下半分は主と して流紋岩熔岩より成るが，基盤岩との接触付近では， 多数の古生層岩石の大塊が捕獲されている。

鉱床は裂力充填鉱床である鉱脈と交代塊状あるい梳鉱 染鉱床である河鹿鉱床とがある(第 1 図参照)。

鉱脈は主として, 流紋岩中に発達し 1,400 余条の多数 に達する。これら 鉱脈は 横間歩一光盛銿に代表される 
$45^{\circ}$ 脈群, 新盛一天狗銿に代表される $90^{\circ}$ 脈群, 蛭子一栄 盛に代表される6 $68^{\circ}$ 脈群に分類できる。前二者は剪断脈， 後一者は張力裂力の性質を有することから, 流紋岩噴出 後 $\mathrm{N} 68^{\circ} \mathrm{E}$ の力向よりの強犬な横圧力により裂力を生成 したものと推定される。

足尾流紋岩中の 鉱脈で注鉱物の晶出は 累帯構造を有
ᄂ, 中心帯 $(\mathrm{Sn}-\mathrm{W}-\mathrm{Bi}-\mathrm{Cu})$, 中間帯 $(\mathrm{Cu}-\mathrm{As}-\mathrm{Zn})$, 周 辺帯 $(\mathrm{Zn}-\mathrm{Pb}-\mathrm{Cu}-\mathrm{As})$ の三帯に分れている。

帯状分布の中心は一つではなく，有力な裂力と裂力と の落合線を中心に鉱化が行なわれた樣子が見られ，この 鉱化の中心は下部に行くにしたがって比較的少数の幹脈 に集約される傾向が見られる。

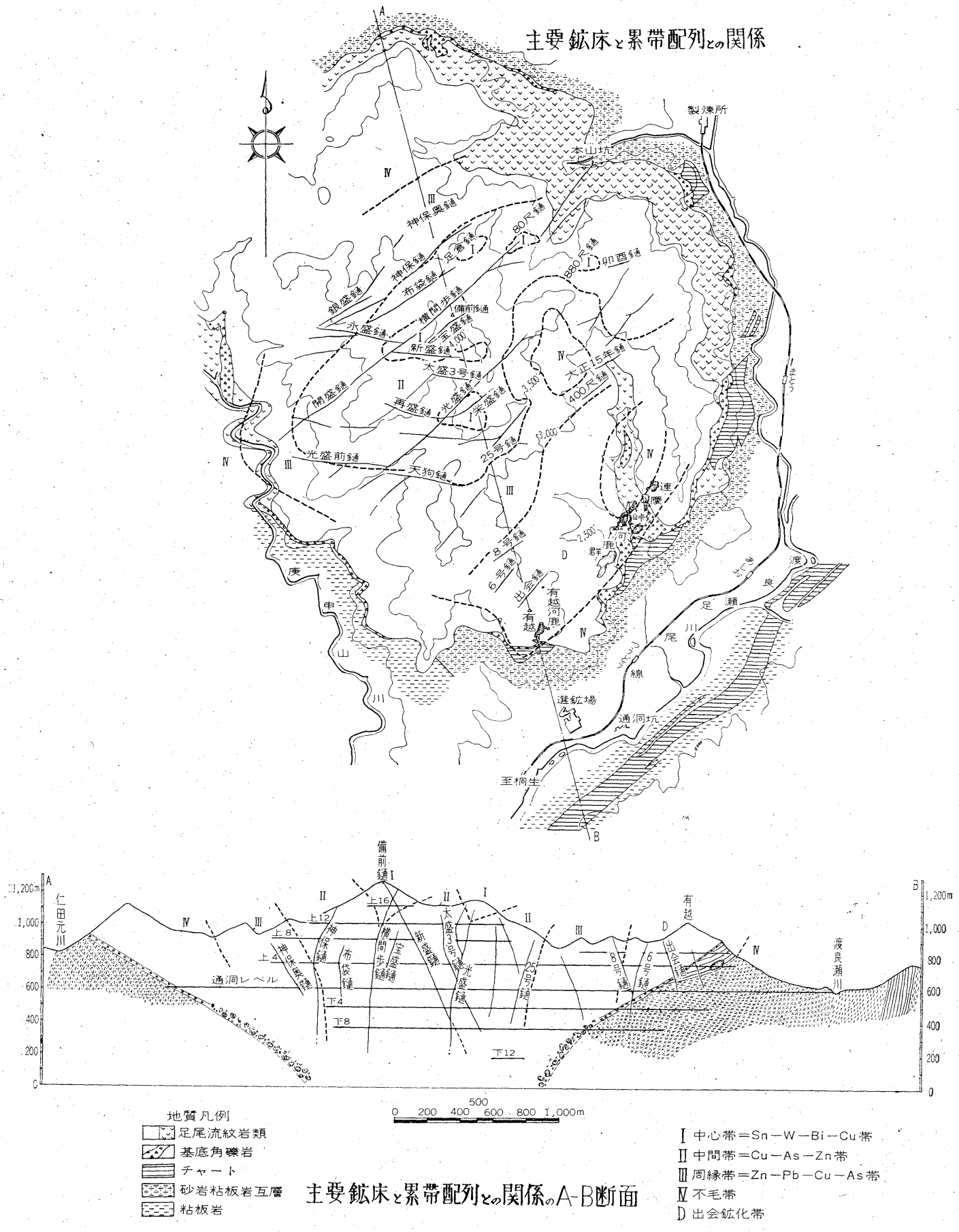

第 1 図 
河鹿鉣床は主として古生層中に存在し，その数 80 余， 連慶洔，有越地帯に集中し，鉱液の上昇路に沿つて現出 する小褔曲や裂力により破砕空隙化の強かつた地帯で鉱 染交代し，河鹿鉱床を形成している。

流紋岩中に挾在する火山砕㞕岩，凝灰角唩岩などの中 に，分散細脈化した裂力が網状鉱染鉱床を形成し，張力 裂カが群をなして発達する地帯，鉣脈の落合部などで は，富鉱部を形成していずれも流紋岩中の河鹿鉱床とな つている。

\section{3. 採掘法}

上部では母岩が比較的堅硬であるため，当所ではほと んど一貫してシニリンケージ採鉱法を主に採用してき た。

現在でも，出鉱の約 $85 \%$ はシニリンケージ法によつて いる。

しかし，下部開発が進み，盤圧の激しい地区を稼行す るようになり，盤返りによる品位低下，抜鉱不能，盤圧 による 鉱石の固結，留の折損増加などの傷害が酷くな り，昭和34年頃には過渡的に坑井組上式シニリンケージ 採鉱法である二式採掘法を採用していたが，工程が悪く 能率が上らないので，昭和38年よりスライム充䁚採掘法 を採用し，現在下部横間歩地区の採掘はすべてこれによ つており, 含位の維持, 保安の向上に効果を発揮してい

1 䇶。押
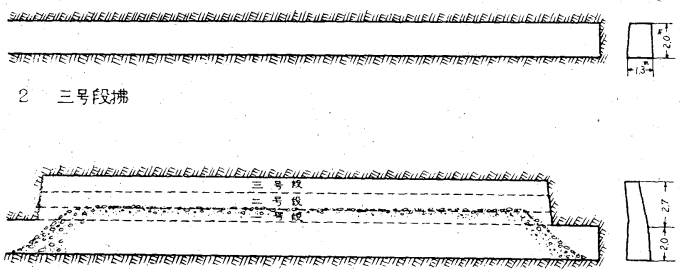

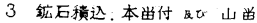

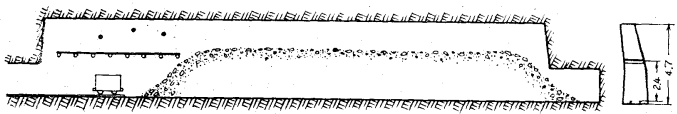

4 湝段又取(漏斗作成)

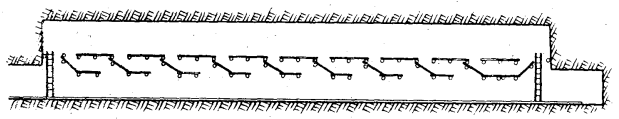

5 シュリンケージ採掘中

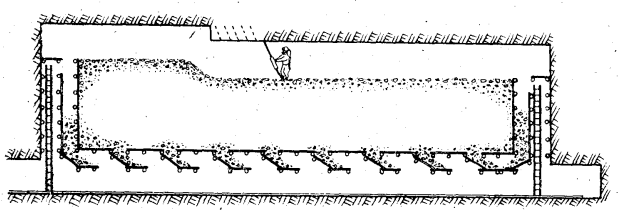

る。

シニリンケージ採掘法（第 2 図参照）では，標準とし

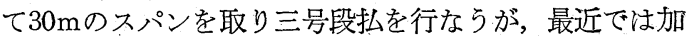
背幅を狭く維持するため上延を制限しているので冠払 4 回が普通となつている。

また採掘スパンは，平均稼行対象が短くなつているの で，稼行対象部分を 1 階段とすることも多く，したがつ

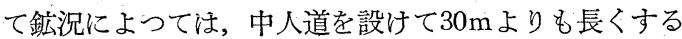
こともある。

三号段払が終了すると，積込と平行して打込留による 本留付，棚掛を行なう。

積込は加背幅に制約され，また切羽が分散しているの で機械の導入が難しく，ほとんど手積に頼つている。

積込終了後, 漏斗付を行ない階段採掘に入る。

穿孔配置は，2 列千鳥型で孔間隔平均 $50 \mathrm{~cm}$ ，スト一 パはほとんど 530Dを，タガネは19mmインサートロッ ドを使用しビットゲージは 33 28mmである。

発破は杉ダイナマイトまたは特紫カーリットを使用 し，D S 電気雷管による電気点火または S Tコードと導 火線による集束点火である。

スライム充塡採掘法(第3図参照)は, 1ブロックを現在 は $30 \mathrm{~m} \times 30 \mathrm{~m}$ にとり，中央に $3.0 \mathrm{~m} \times 1.5 \mathrm{~m}$ の切上りを上 部坑道に貫通させ後三号段払を行ない留付，棚掛をする が、下部では盤が悪いので坑道留によるのが普通である。

6 シュリンケージ採掘完\}

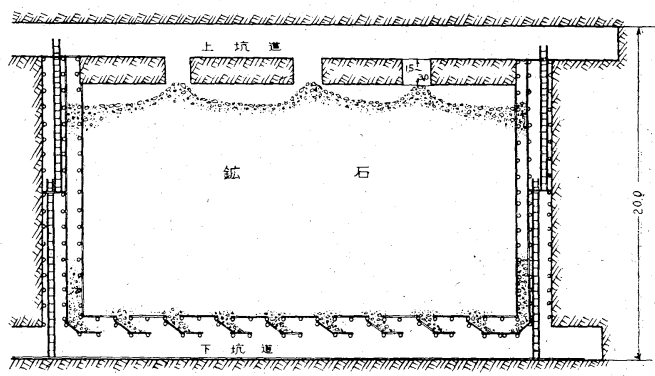

7 潰拔及飞充填

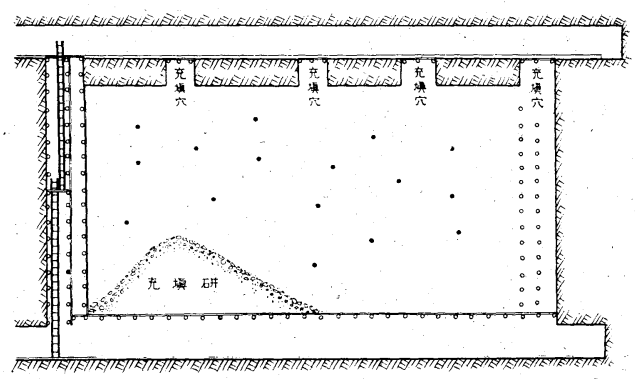

㯰拔中の膄段内の山酋

第 2 図 シニリンヶージ採掘順序 

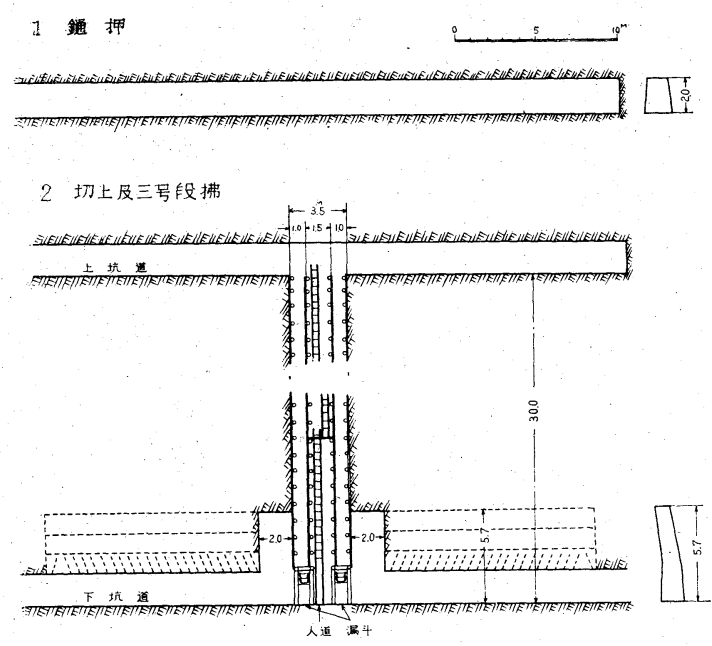

3 階段段取

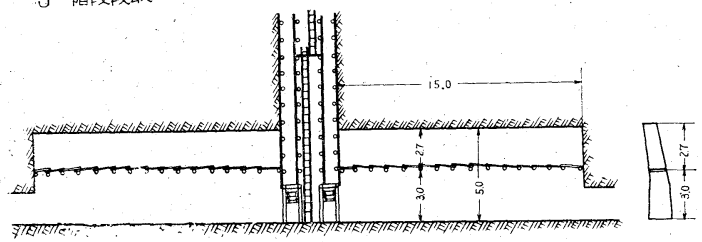

第3図充填採掘順序

第3 表 採掘法別出鉱量拈よび切羽数

\begin{tabular}{|c|c|c|c|c|}
\hline 採掘法の種類 & 出 鉱 量 & 出鉱比率 & 切 & 羽 数 \\
\hline シュッンム方充填 & $\begin{array}{r}32,956 \\
3,787\end{array}$ & $\begin{array}{l}90 \\
10\end{array}$ & & $\begin{array}{r}173 \\
12\end{array}$ \\
\hline
\end{tabular}

第 4 表 開探鉱出鉱量扣よび試錐趧長

\begin{tabular}{|c|c|c|c|c|c|}
\hline \multirow{2}{*}{$\begin{array}{c}\text { 試錐㱏長 } \\
(\mathrm{m})\end{array}$} & \multirow{2}{*}{$\begin{array}{c}\text { 探鉱延與 } \\
(\mathrm{m})\end{array}$} & 出 & 鉣 & 量 & $(t)$ \\
\hline & & 開探釷 & 採 & 鉱 & 計 \\
\hline 118.10 & 385.95 & 7,526 & & 737 & 44,263 \\
\hline
\end{tabular}

切羽は比較的集約されているので，積込には太空 500 または $600 \mathrm{~B}$ 型ローダを使用し，棚上にスライムを初充 塡して採掘に入る。鉱石搔込は $5 \mathrm{P}$ スクレーパーを使用 し，充㙗スライムは坑外よりマルスポンプにより直送す る。せん孔配置はシニリンケージと同じであるが，点火 はすべて電気発破である。

切羽人員は請負組夫によつているので一定でないが, 大略 3 名くらいである。スクレーパーホイストの移設は 1 ブロック採掘に 2 回位で, ホイストの運転はワイヤを 引張つてリモートコントロールする。
4 充媞握掘

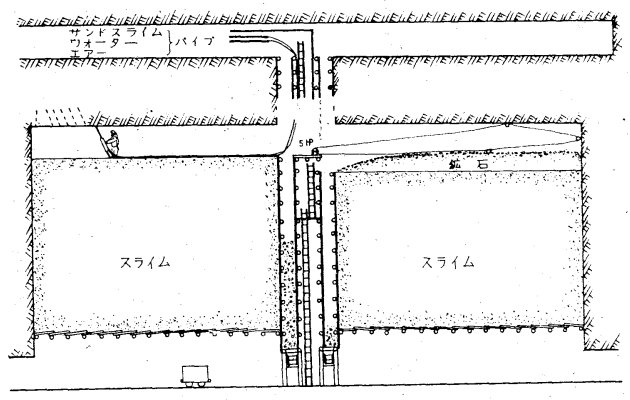

5 竜領柫
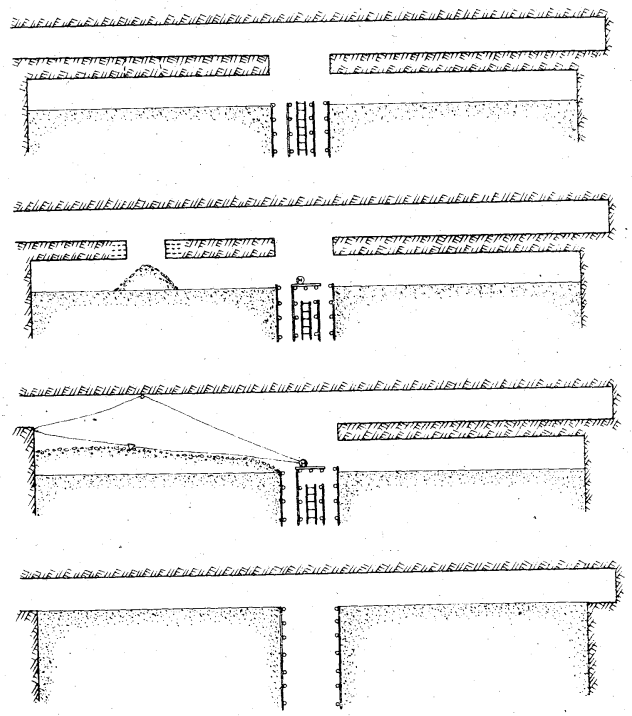

加背幅を狭く維持するためスクレーパは幅 $500 \mathrm{~mm}$ の ものを使用して仕上り加背幅 $100 \mathrm{~cm}$ 前後で採掘してい る。

\section{4. 運搬}

鈗石は普通上部系統では $0.5 \mathrm{t}, 0.7 \mathrm{t}$ 三角鉣审および $1.0 \mathrm{t} ， 1.5 \mathrm{t}$ 角開閉鉱車により手押で各坑井に投入す る。本山坑上部の鉱石は上 4 番坑で一度 $4.5 \mathrm{t}$ トロリー 電車により集結し通洞地並に通ずる集中坑井に落す。

通洞地並末端でトロリ一電車の大らないところは 2.0 $\mathrm{t}$ バッテリーロコを配備して集車しトロリ一電車操車場 まで引きつける。

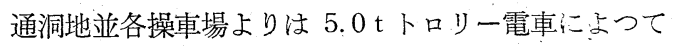
エンドレス斜坑停車場まで運搬する。

第 5 表 採掘法別工程原単位および直接採掘・採鉱費

\begin{tabular}{|c|c|c|c|c|c|c|c|c|c|c|c|c|c|c|c|c|c|c|}
\hline & \multirow{2}{*}{\begin{tabular}{|c|}
$\mathrm{t} /$ 採掘量 \\
$\mathrm{t} /$ 月
\end{tabular}} & \multirow{2}{*}{$\begin{array}{l}\mathrm{m}^{3} / \mathrm{t} \\
\end{array}$} & \multicolumn{2}{|l|}{ I } & 数 & \multicolumn{5}{|c|}{ 原 単 位（粗鉱 $\mathrm{t}$ 当り） } & \multicolumn{4}{|c|}{ 值接採掘費 $\mathrm{t}$ 当 } & \multicolumn{4}{|c|}{ 㨁接採鉱費 $\mathrm{t}$ 当 } \\
\hline & & & 採掘 & 充填 & 柿 & 工数 & 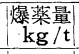 & $\begin{array}{l}\text { 坑末 } \\
\mathrm{m}^{3} / \mathrm{t}\end{array}$ & $\begin{array}{l}\text { 鋼材 } \\
\mathrm{kg} / \mathrm{t}\end{array}$ & $\begin{array}{l}\text { 電 力 } \\
\mathrm{kWh} / \mathrm{t}\end{array}$ & 人件 & 物品 & そその他 & 柿 & 人件 & 物品 & Z心他 & 計 \\
\hline シュリンヶーシ & 32,956 & & 15,408 & & & 0.43 & 0.813 & 0.008 & 0.07 & 19.5 & 400 & 200 & 200 & 800 & 1,100 & 400 & 300 & 1,800 \\
\hline
\end{tabular}


下部方面では各坑道に $2.0 \mathrm{t}$ バッテリーロコを配備し 立坑まで引きつけ, 布袋, 前銿方面はケージ巻で通洞地 並まで, 横間歩方面では $1.5 \mathrm{t}$ 鉱車を使用し上 8 までケ 一ジ巻で, ここから光二立坑まで $5.0 \mathrm{t}$ トロリ一電車に より，3.0 t 鉱車を使用して運搬し，スキップ巻上によ

り通洞地並まで巻き上げられる。

エンドレス停車場に集結した鉱車は選鉱場まで高さ 44 $\mathrm{m}$, 延長 $174 \mathrm{~m}$ のエンドレス斜坑を巻き上げられる。

主要坑道のレールには15, 12, $10 \mathrm{~kg}$ のもを使用し, 切羽では $6,9,10 \mathrm{~kg}$ のレールを使つている。

レールゲージは $480 \mathrm{~mm}$ であるが, 光二下 8 のみ $762 \mathrm{~mm}$ となつている。

廃石注充填場の得られる所はすべて坑内で処理するが 残余のものは鈗石と同しく巻き上げられ，坑外堆積場ま でトロリー電車により運搬される。

立坑はすべてブラインドで11カ所あり上部の諸立坑お よび下部光一，横三立坑などは人員資材の運搬，布袋， 横閒歩立坑はケージによる荷巻と人員, 資材の搬入を兼 ね, 光二立坑はスキップによる鉱石巻上を主として行な つている。

切羽末端部立坑より還隔の地点では 1.0 5. OP の圧 気動ホイストを採掘跡, 切上りなどを利用して資材搬入 の便に供している。

\section{5. 通気, 排水, 照明, その他}

旧坑が網の目のよらに発達している関係上，全般的な 機械通気は不可能であるが，自然通気は上下の系統に分 れて良好に配分されており，常時入坑者に対して必要充 分な大気量がある。すなわち上部は上 4 以上小滝, 本山 両坑口と無数に存在する旧坑との間で通気路を作り，下 部では前銿，横間歩両立坑系による通気路を作つてい る。

上部は季節変化による気温の逆転で風向が変わるが, 下部は温度変化なく風向は常に一定である。

3,4 月頃の総入気量は概略 $5,000 \mathrm{~m}^{3} / \mathrm{min}$ あり, 半分以 上は上部系統に迴つている。

しかし切羽末端では部分的に通気不良の個所があり， このような場所ではエヤージェットを使つたり, 圧気を 一時的に吹かすことで問題を解決している。

坑内気温は通洞以上で $15^{\circ} \sim 18^{\circ} \mathrm{C}$, 下 10 で $23^{\circ} \sim 25^{\circ} \mathrm{C}$ (最 高 $28^{\circ} \mathrm{C}$ ), 下 $12 て ゙ 25^{\circ} \sim 30^{\circ} \mathrm{C}$ (最高 $32^{\circ} \mathrm{C}$ ), 湿度は平均 $93 \%$ くらいとなつている。

通洞方面, 通洞地並以上の坑内水は排水溝により,下 部は横間歩，横三，前銿方面はポンプにより通洞地並へ 揚水し，上部の水と合せて中才浄水池入入れる。

本山方面の上部の水の一部之, 本山有木地並以下の横 二下3ポンプで揚水された水は通洞へ排水されるが,残余
の水は本山坑より排水溝により間藤浄水池へ送られる。 坑内水の平均湧出量は通洞坑口で $10 \mathrm{~m}^{3} / \mathrm{min}$ 前後であ るが，渴水期には最低 $7 \mathrm{~m}^{3} / \mathrm{min}$ ，増水期では $13 \mathrm{~m}^{3} / \mathrm{min}$ くらいである。下部よりポンプによる揚水量は 4.4 7.2 $\mathrm{m}^{3} / \mathrm{min}$ で平均 $6.0 \mathrm{~m}^{3} / \mathrm{min}$ 程度で5 7段の $50 \sim 200 \mathrm{P}$ 程 度のタービンポンプで 1 回の揚程を $100 \sim 200 \mathrm{~m}$ にとり 自動運転により排水される。

坑内主要廊下は電灯, 螢光灯による照明を行なつてい る。切羽ではアルカリ電池のキャップランプを使用して いる。

電力は自家発電電力を使用し，採鉱関係で月約 135 万 $\mathrm{kWh}$ あるかが，その使用比率は圧気 $49 \%$, 排水 $39 \%$, 巻 上 $7 \%$, 電車 $2 \%$, その他 $3 \%$ となつている。

本山, 通洞両坑口より 2 系統に分れて 3 相 50 サイクル $2,000 \mathrm{~V}$ 電気を送り, 電車用は $500 \mathrm{~V}$ 直流に整流して送 つている。

圧気は本山, 通洞の 8 台のコンプレッサーで $5.5 \mathrm{~kg}$ / $\mathrm{cm}^{2}$ のものを送つているが，最近ピーク時に圧気圧の低 下が著しいので坑内に $600 \mathrm{PP}$ のコン゚レッサーを増設し た。

\section{6. 問題点と将来の計画}

当所は産出鉱物が銅単味であるため副産物収入を期待 することができない。また細脈で能率も悪いことから， どらしても品位を高く維持していく必要がある。従来と も採掘加背幅の縮少に努めてきたが, 加背幅の縮少によ る品位の上昇と機械化とが両立しない。

近年, 労働力の確保が次第に困難となり，良質の労働 力が得難くなつていることから, 必然的に坑内の機械化 を進めて生産性を高める必要があるが，依然として細脈 に適する機動性のある小型の機械はほとんど開発されて いない現状である。

高品位地区である下部開発には鋭意努めているが，下 へ行くにつれて坑内気温の上昇が問題となつてきてい る。下部ではこのため通気系統の整備が急務となつてき たが，上部採掘系の旧坑が網の目のように発達している ので効果的な通気が困難である。

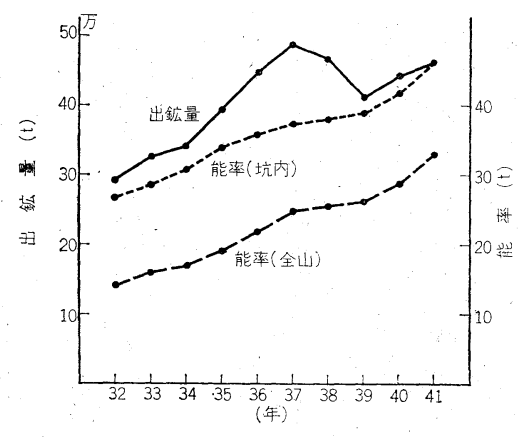

第 4 図 
粗鉣搬出系統では選鉱場までエンドレス斜坑巻上をし ているが，巻上能力が低く，故障が多いため出鉱のネッ クとなつているが, 出鉱を阻害せずに改修する点で問題 がありまだ改善されていない。

以上の問題を解決するため, 立坑設備, 選鉱受入, コン プレッサー運転など自動化できるものは極力自動化して 人員の節減を計ること, またさく岩能率向上のための新 しいさく岩装置の研究, 下部高品位地区の開発を更に進 めて, ここからの出鉱比率の増加などを計画している。

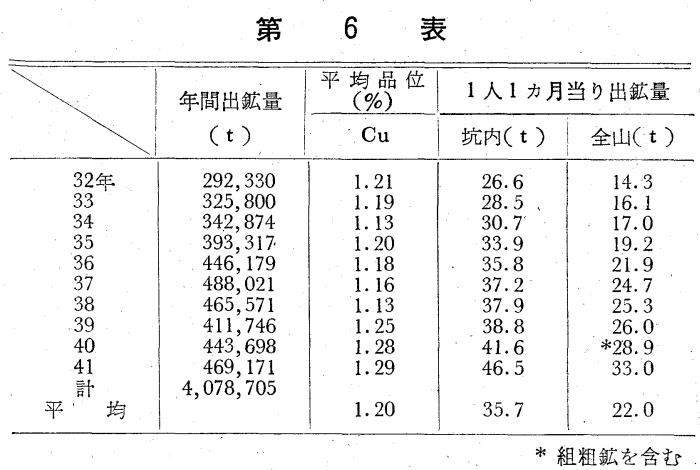

\section{鉱}

\title{
Nikko Mine
}

\author{
正会員 三 浦 清三郎* 中 里 光 一* \\ Seizaburo MIURA Kōichi NAKASATO
}

\section{1. 緒言}

位置; 日光鉱山は杤木県塩谷郡盐谷町船生にあり，宇 都宮市の北北西直距 $26 \mathrm{~km}$ に位置する。国鉄東北本線矢 板駅から東武鬼怒川公園行バスに乗り換え西進約 $15 \mathrm{~km}$ または東武鬼怒川線新高徳駅から矢板行きバスにて東進 約 $12 \mathrm{~km}$ で鉱山事務所化達する。

沿革; (杤木鉱山)

明治37年 発見

同 39 年 露頭採掘, 天頂鉱山之称す。

大正 8 年 上田鉱業となり，第 1 次大戦終了により休

山。

昭和 3 年 久原鉱業が買収し杤木鉱山と改称。

同 7 年 久原鉱業が日本鉱業と改称，買収した日光

鉱山どあわせ日光鉱業所として発足。

同 34年 年間銅量500 t を産出。

同 37 年 日本鉱業森より分離し日光鉱山(㑣となる。

現況；(第1,2表参照)

\begin{tabular}{|c|c|c|c|c|c|c|}
\hline \multirow{2}{*}{\multicolumn{3}{|c|}{$\begin{array}{c}\text { 第 } 1 \text { 表 } \begin{array}{c}\text { 粗鉱量と出鉱品位 } \\
\text { (昭和 } 42 \text { 年 } 3 \text { 月実績) }\end{array} \\
\end{array}$}} & \multicolumn{4}{|c|}{$\begin{array}{r}\text { 第 } 2 \text { 表 従 業 員 } \\
\text { (昭和 } 42 \text { 年 } 3 \text { 月実績) }\end{array}$} \\
\hline & & & & 坑内 & 坑外 & 計 \\
\hline \multirow{2}{*}{$\begin{array}{c}\text { 粗 捈 量 } \\
\text { ( } \mathrm{t})\end{array}$} & 品 位 & $(\%)$ & \multirow{3}{*}{ 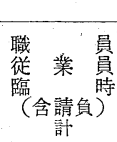 } & \multirow{3}{*}{$\begin{array}{r}9 \\
77 \\
48 \\
134\end{array}$} & \multirow{3}{*}{$\begin{array}{l}18 \\
51 \\
18 \\
87\end{array}$} & \multirow{3}{*}{$\begin{array}{r}27 \\
128 \\
66 \\
221\end{array}$} \\
\hline & $\mathrm{Cu}$ & s & & & & \\
\hline 4,200 & 1.03. & 3.18 & & & & \\
\hline
\end{tabular}

\section{2. 地質鉱 床}

当鉱山付近の地質は，白亜紀の石英斑岩と新第三紀中 新世の火山岩ならびに火山砕屑岩および第四紀層からな り，その岩層は下表のようである。

\begin{tabular}{|c|c|c|c|}
\hline \multicolumn{2}{|c|}{ 地質時代 } & 地 圈 名 & 岩 \\
\hline \multicolumn{2}{|c|}{ 第四 紀 } & 洪 積 買 & 関東ローム層 \\
\hline \multirow{3}{*}{ 新 } & \multirow{3}{*}{$\begin{array}{l}\text { 中 } \\
\text { 新 } \\
\text { 世 }\end{array}$} & 赤坂流紋岩 & \multirow{2}{*}{$\begin{array}{l}\text { 流狳岩 } \\
\text { 斜長流紋岩（珪長岩を伴 う） }\end{array}$} \\
\hline & & 天頂流紋岩 & \\
\hline & & 船生凝灰岩 & 浮石質凝灰岩層 \\
\hline \multicolumn{2}{|c|}{ 白亜紀 } & 石英斑岩 & 石英斑岩（古生層？の碅を含む） \\
\hline
\end{tabular}

地層の走向，傾斜は顕著な構造が認められないので分 明でないが，おおむ称走向 N NE〜S S W，傾斜は $20^{\circ}$ Wである。

鉱床は，石英斑岩ないし流紋岩扩よび凝灰岩中の裂力 充壝型単純銅鉣脈鉱床で, 日光鉱床と栃木鉱床とがあ る。前者は主として石英斑岩中に胚胎するが現在は稼行 休止している。

杤木鉱床は，東部四号，東部 1 号，11号銿，下盤銿， 上盤脈， 4 号銿など $\mathrm{N}-\mathrm{S}$ 系の剪断脈主脈と， NEまた はNW系の張力脈の支脈とからなり，いずれも西傾斜で 合計約 30 脈が知られている。

これらの鉱脈は, 東西 $1 \mathrm{~km}$, 南北 $1 \mathrm{~km}$ の範囲に分 布し鉱床中心部に法走 $\mathrm{N}-\mathrm{S}$ の 3 条の岩脈 (黒雲母石 英斑岩）がみられ，西部の岩脈と中央部のものとの間で は鉱脈の密集帯を形成している。主脈は，走向延長 300 $\mathrm{m}$ 以上，傾斜延長 $200 \mathrm{~m}$ 以上の連続を示すが，支脈は裂 カ単位が小さい。

釷石鉱物は，黄銅鉱，黄鉄鉱を主とし 斑銅鉱，輝銅

* 日光鉣山株式会社栃木鉱業所 